\title{
分岐部動脈瘤の流れの可視化
}

氏家 弘, 吉本 成香, 堀 智勝
稲垣 進, 石橋 幸男, 武田秀一郎

\section{Flow Visualization Studies of Bifurcation Aneurysm}

Hiroshi UjIIE, M.D., Shigeka Yoshimoto, Ph.D., Tomokatsu Hori, M.D., Susumu Inagaki, Ph.D., Yukio Ishibashi, Ph.D., and Shuichiro Takeda

Department of Neurosurgery, Neurological Institute, Tokyo Women's Medical University, Tokyo, Department of Mechanical Engineering, Science University of Tokyo, Tokyo, Department of Mechanical Engineering, The National Defense Academy, Yokosuka, and Aircraft Maintenance Course, Chiba Polytechnic College, Chiba, Japan

Summary: We conducted flow visualization studies and measurements of intraaneurysmal flow volume using a flat three-dimensional acrylic aneurysm model. Flow visualization was done by the tracer particle technique and the particle streamlines were pursued through a charge-coupled device (CCD) camera. Analysis of intraaneurysmal flow volume was carried out by means of dye injection. Monitoring of time-related concentration of the aneurysms allowed calculation of the mean transit time (MTT) using the height-over area method. Fundamental intraaneurysmal flow was composed of inflow, circulation flow, and outflow. These fundamental flow patterns were strongly influenced by the flow ratio into the distal branches. A nearly symmetric flow ratio failed to achieve full intraaneurysmal flow. The critical flow ratio to raise inflow into an aneurysm was considered to be $3: 1$, and the best flow ratio to develop intraaneurysmal flow in our three-dimensional model was $4: 1$. An increase of the aneurysmal size and changes in geometrical features such as the daughter formation, the dumbbell shape narrowing and narrowing of the neck led to a stagnant area or very sluggish flow area at the dome side. Geometries favoring aneurysmal rupture are considered to be closely associated with low-flow condition.

\section{はじめに}

高解像度 CT スキャンおよびMRAの発達に伴って, 健 康被検者に未破裂脈動脈瘤の発見される機会は, 増えてき ている.さらに最近の MRAおよびへリカル CTスキャン では, 直径 $3 \mathrm{~mm}$ 弱の脳動脈瘤でさえ探知できるようにな った ${ }^{7)}$ 19). つた

東京女子医科大学 脳神経センター脳神経外科(受稿日 1998.12.9)〔連絡先： †162-8666 新宿区河田町 8-1 東京女子医科大学 脳神経 センター脳神経外科氏家 弘〕〔Mailing address: Hiroshi UjIIE, M.D., Department of Neurosurgery, Neurological Institute, Tokyo Women's Medical University, 8-1 Kawada-cho, Shinjuku-ku, Tokyo 162-8666, Japan]
しかし脳動脈溜の発生, 成長, 破裂に至るメカニズムは 十分に解明されていないため, 現在のところ，どのような 動脈瘤が近い将来破裂するかということを予測することは 難しく, そのため未破裂脳動脈溜の手術適応基準はない4).

脳動脈瘤の発生，成長破裂のメカニズムには，血液の流 れによる hemodynamic stress と動脈瘤壁の脆弱性が密接 に関係している3 14)17)。しかしながらわれわれが臨床上

\author{
Key words: \\ - intracranial aneurysm \\ - hemodynamics of \\ intracranial aneurysm
}

Surg Cereb Stroke

(Jpn) 27: 439-445, 1999 
用いる診断技術は, ほとんど画像診断に限られているので, 動脈㧍よび動脈瘤の形態は推測できても, それを構築して いる血管壁または動脈瘤壁の材料特性を，推測することは できない. そのため血管の形態，そしてそれによって生じ る流れから，血管壁がどのような影響を受けるか，ひいて はどの部に血管壁の脆弱性が生じるか, モデルを用いて研 究することはきわめて価值がある. 現在まで数多くのモデ

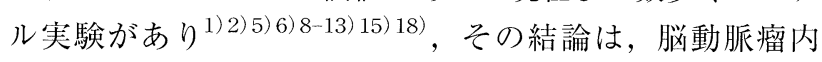
の血流はきわめて遅く, 流れによって生じる shear stress もきわめて低いため, 脳動脈瘤の成長, 破裂の流れに大き な影響を与えないというものである ${ }^{12) 13)}$. 一方，動脈瘤 の orificeには流れによる高振動, それに伴う乱流によっ て動脈瘤壁に破壊的変化をもたらすという報告もある ${ }^{11)}$ 16).

これらの論文では, 動脈瘤の形態および流れを定量的に 変化させて結論を導いたものではないので, 同じように比 較することはできない. 今回，われわれは平面的三次元モ デルを用いて分岐部動脈瘤を作成し，その分岐部末梢部の 流れの変化が動脈瘤内の流れに与える影響を定量的に検討 した。また, 大きな動脈瘤, blebを有した動脈瘤, dumbbell型をした動脈瘤など, いわゆる破裂動脈瘤が有する共 通した流れの特徴を解析した。

流れの可視化をナイロン粒子を用いて行い, 流れの定量 的な検討をインク注入による濃度分布の変化から流量を推 定して行った.

\section{方 法}

アクリルを用いて三次元平面動脈瘤モデルを作成した
(Fig. 1).中心導管は幅 $20 \mathrm{~mm}$, 厚さ $5 \mathrm{~mm}$ の長方形断面 を分岐管は非刘称的で幅 $17 \mathrm{~mm}$, 厚さ $5 \mathrm{~mm}$ および幅 $14.5 \mathrm{~mm}$, 厚さ $5 \mathrm{~mm}$ の長方形断面とし, その分岐角度は $140^{\circ}$ とした．動脈瘤は分岐部に中心から $3 \mathrm{~mm}$ ほど太い 分岐管のほうへずらして卵円形に作製した。その orifice の直径は $20 \mathrm{~mm}$ で厚さは $5 \mathrm{~mm}$, 大きさはneck-to-dome: $32 \mathrm{~mm}, 48.5 \mathrm{~mm}$ の 2 種類を作製した. neckを太い分岐管 側へずらしたのは，できるだけ実際の脳動脈瘤の形態を模 倣するためである. blebの作製, dumbbell型動脈瘤の作 製は， $32 \mathrm{~mm}$ モデルに粘土を加えて作製した。

流れの可視化はナイロン粒子 (mean diameter: $90 \mu \mathrm{m}$, Specific gravity: 1.01)を用いて行った. ナイロン粒子の流 跡は CCDカメラでモニターし, video capture board DIG98に記録した. 1秒間に5-30枚の流れ画像を取り达 むことによってそれぞれの粒子の速度 profile を測定した。

動脈瘤内の流量は, あらかじめ瘤内底部から頸部に小さ い穴を開けインクを誘導し動脈瘤内を満たしたのちに，流 れを作り, 動脈瘤内インク濃度を video で持続測定するこ とで, 動脈瘤内の時間濃度曲線を得た。その時間濃度曲線 を指数関数に fitting させ mean transit time (MTT) を下記 のStochastic Analysisから求めた.

$$
t=\int c(t) d t / c(o)
$$

今回の実験では，実際のヒトWillis circle で予測される Reynolds 数 300-600の定常流で行った. Willis circleでは, 心拡張期では血流速が低下し, Reynolds 数は 300 前後に, そして心収縮期では血流速は加速され, Reynolds 数は 600 前後になると報告されている ${ }^{18)}$. Reynolds 数は dimen-

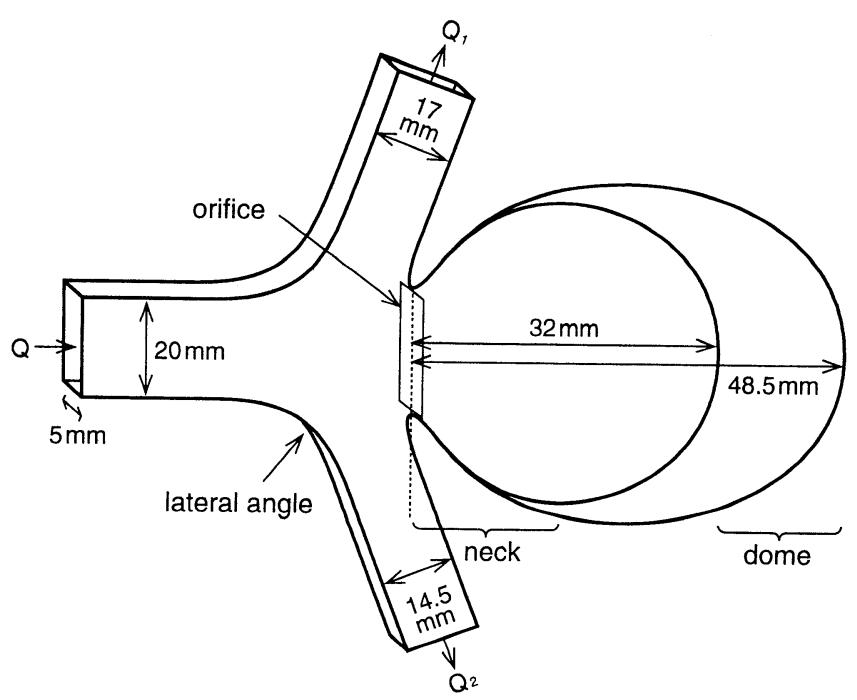

Fig. 1 Geometry of the bifurcation aneurysm. A position of the orifice, neck and dome are indicated. Slightly asymmetric bifurcation with a standard and large aneurysm were used for the experiment. 


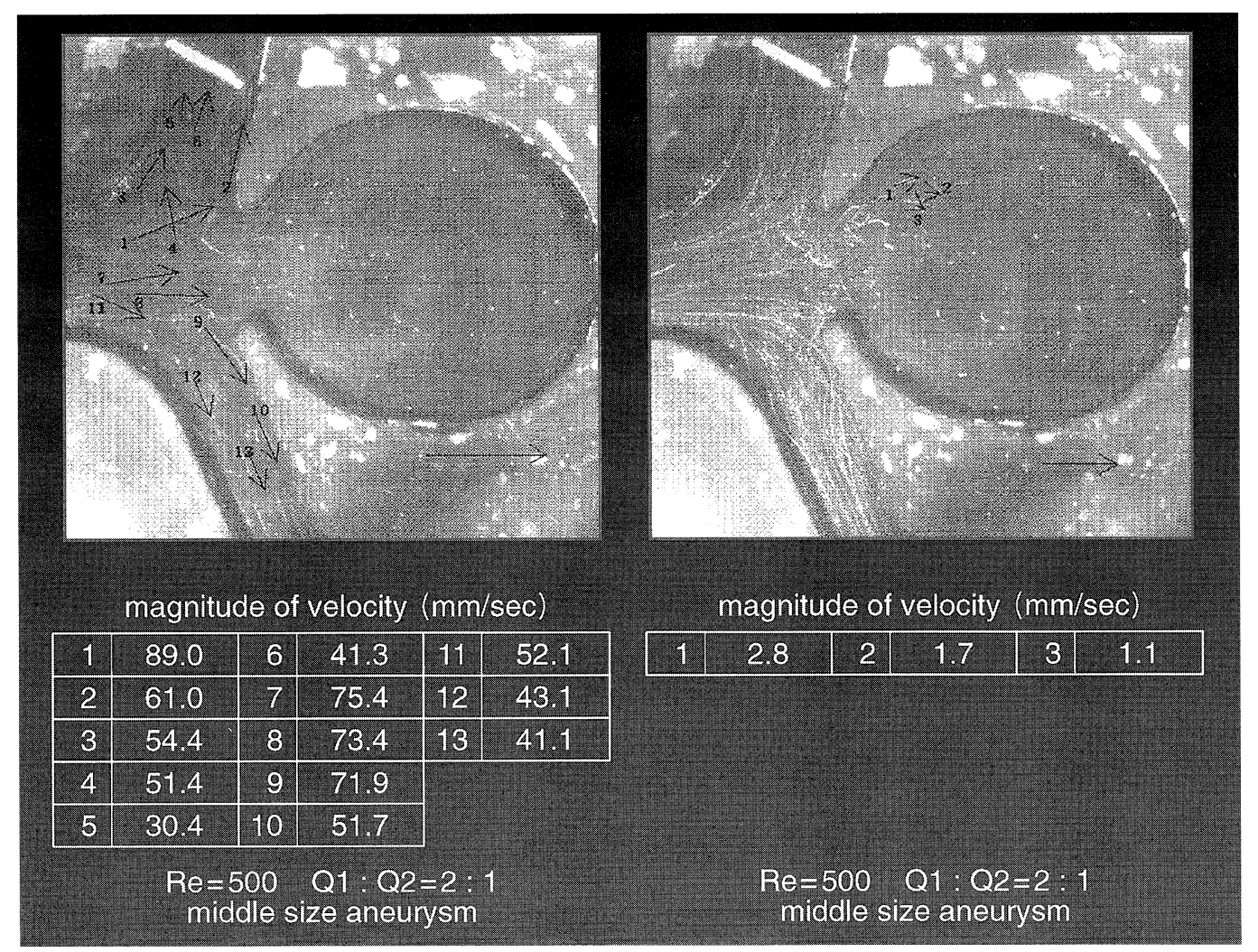

Fig. 2 Flow pattern of the standard aneurysm at a flow ratio into the distal branches of $2: 1$ and at a Reynold's number of 500. The line is the paths of the particles and the numbers on the paths indicate the particle linear velocity on the table. Since the velocity inside the aneurysm was very slow comparing with those in the parent tube, extremely long time was necessary to pursue the each particles. Intraaneurysmal flow is restricted to the neck area and the dome is almost stagnant.

sion を持たない数值で, 形態が相似しているモデル間の流 れを比較する場合には，一致していなければならない。す なわち，モデルの大きさ，使用する流体の粘度がモデル間 で違う場合，同じ流れを期待するためには Reynolds 数が 一致していなければならない. Reynolds 数は下記の式で 表される.

$$
\operatorname{Re}=\mathrm{UD} / v
$$

ただし $\mathrm{U}(\mathrm{m} / \mathrm{second})$ は導管の平均流速, $\mathrm{D}(\mathrm{m})$ は導管 の径, $v\left(\mathrm{~m}^{2} / \mathrm{second}\right)$ は流体の運動粘性係数 (kinematic viscosity)を表す。この実験系ではDおよび $\mathrm{D}$ が定数なの で，分岐管の末梢抵抗を変化させることによって，流速を 換えて Reynolds 数を変化させ，また分岐流量比も変化さ せた。

\section{結 果}

\section{可視化実験}

モデルを用いた流れの可視化は定常流で行った。
Reynolds 数と末梢分岐管の流量比 $(\mathrm{Q} 1 / \mathrm{Q} 2)$ を変化させ, 動脈瘤内に生じる流れの変化を定量的に検討した。基本的 な流れのパターンは, Reynolds 数によって変化せず, 流 量比の変化とともに変化した. しかし動脈瘤内の流れ速度 および渦流れの大きさは, Reynolds 数と正の相関を示し た。

流量比が2：10とき, 中心導管の測度分布はほぼ放物 線状で対象的であるため, 主流は動脈瘤 orifice 部で衝突 し, 動脈瘤内に入ることはなく, 衝突後, 分岐管へと流れ ていく(Fig. 2).わずかな流れが動脈瘤の neck部に, 分 岐管流量の多い側で認められた。流れの衝突のために, 動 脈瘤 orifice 部では高振幅の複雑な流れが，生じていた。 動脈瘤の dome 側は, ほとんど流れのない停滞した領域と なっている。この流れ分布の特徵は Reynolds 数を上昇さ せたときにもほとんど変わらず, 動脈溜 orifice 部の高振 幅な複雑な流れが増強されるだけであった。また，動脈瘤 の domeのサイズを変化させても流れのパターンにはまっ たく影響がなかった. 流量比をこれ以上に変化させると, 


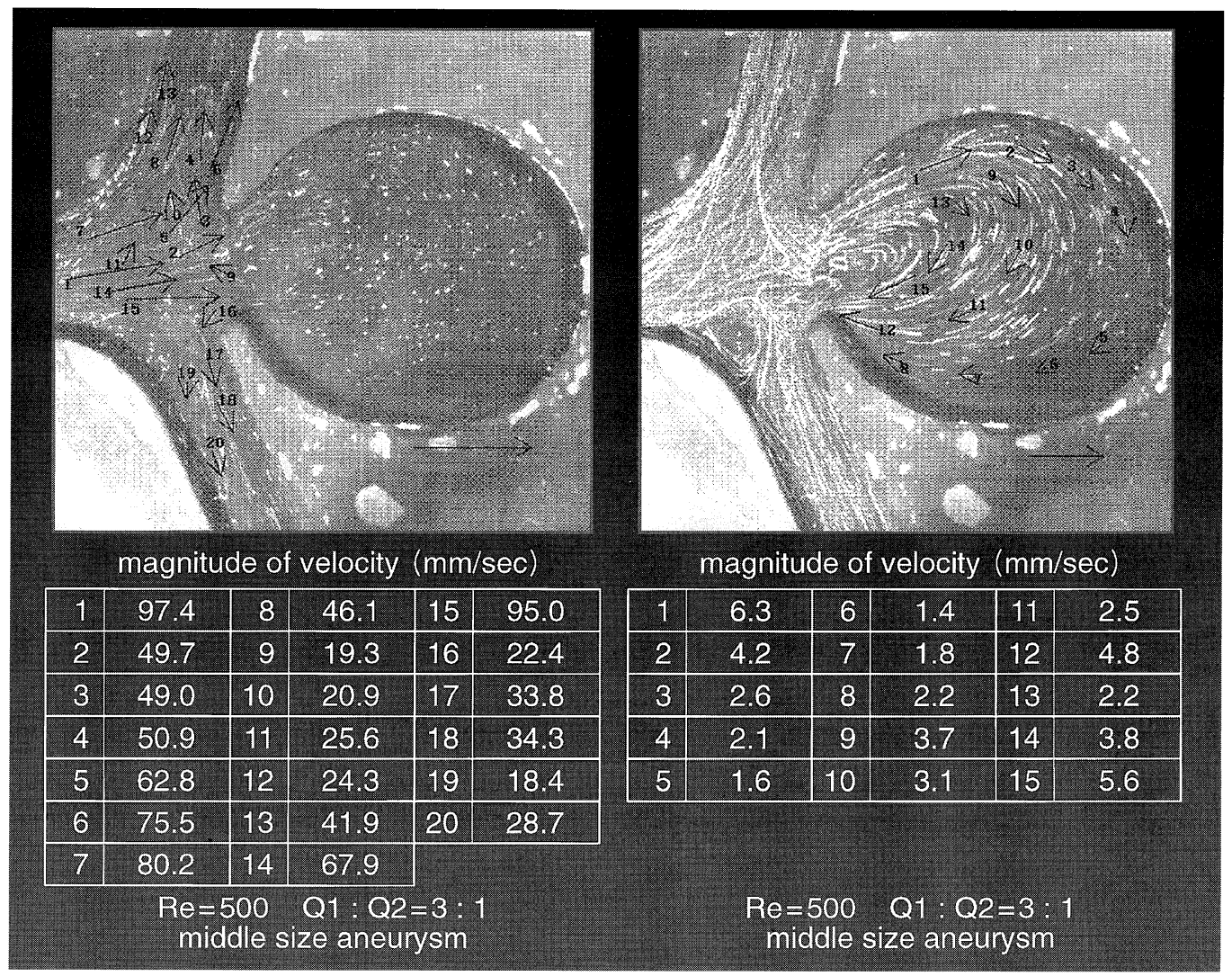

Fig. 3 Flow pattern of the standard aneurysm at a flow ratio into the distal branches of $3: 1$ and at a Reynold's number of 500. The line is the paths of the particles and the numbers on the paths indicate the particle linear velocity on the table. Left photograph shows the velocity pattern in the parent tube, and right photograph shows the velocity pattern in the aneurysm. The flow impinges upon the larger flow side orifice making collision and then enters inside reducing its velocity. After making vortices flow the flow goes out through the opposite orifice.

動脈瘤内へ流れが生じた。流量比を $3 ： 1$ にした場合，中 心導管の主流は流量比の多い側へ偏位し，そして，流量比 の多い側から動脈瘤内に流入した(Fig. 3). しかしこの時, 動脈瘤 orifice 部には流れの衝突とそれによる高振幅の振 動が忍められ，一部の流れだけが，動脈瘤内に入ることが わかった，そのため流れは，衝突によってその多くのエネ ルギーを奪われ，動脈瘤内に流入した流れの速度は，中心 導管の主流の速度の $10 \%$ 程度に低下していた。この流入 した流れは domeに到達し, そこで反転し, 一次流れは反 対側の分岐管へと流出した。この特徵的な流れのパターン はReynolds 数を 300 と低下させた場合，および動脈瘤の domeを大きくした場合, 流入流れの速度が低下したため, 全体にゆっくりしたものとなった。このような場合には， 動脈瘤内の一次渦流れが neck 付近に生じ, dome側では 遅い拡散流れが生じた。

さらに流量比を増大させた場合，すなわち流量比 $4: 1$ 以上では中心導管の主流は, 動脈瘤 orifice 部でまったく
衝突せずに動脈瘤内に入った (Fig. 4). そのため動脈瘤内 の速度は, 主流に対して 2 分の 1 から 3 分の 1 程度にしか 減少しなかった。この流入流れは, 1 次洞流れを作り反対 側の分岐管へと流出した．流入流れが domeに到達した部 で1次渦流れの反対側に 2 次洞流れを作った。この 2 次洞 流れの速度はきわめて遅く, 中心導管主流の 10 分の 1 以 下であった。この基本的なパターンの流れは, 動脈瘤の domeを大きくしても，またReynolds数を低下させても 変化しなかったが, 動脈瘤内速度は低下した。分伎部にお ける分岐管外側部で，管壁からの流れの剝離と剝離した 部への逆流する2次渦流れが生じた。この現象は流量比の 少ない側に, そして Reynolds 数の高いときそして流量比 の差の大きいとき明確に生じた。

動脈瘤の形態で domeに にlebを作成した場合, domeに dumbbell 状の狭窄部を作成した場合, そして動脈瘤の orificeを狭窄した場合，流れはその末梢でその速度を著しく 低下させた (Fig. 5)，すなわち動脈瘤は，ふくらんだ盲端 


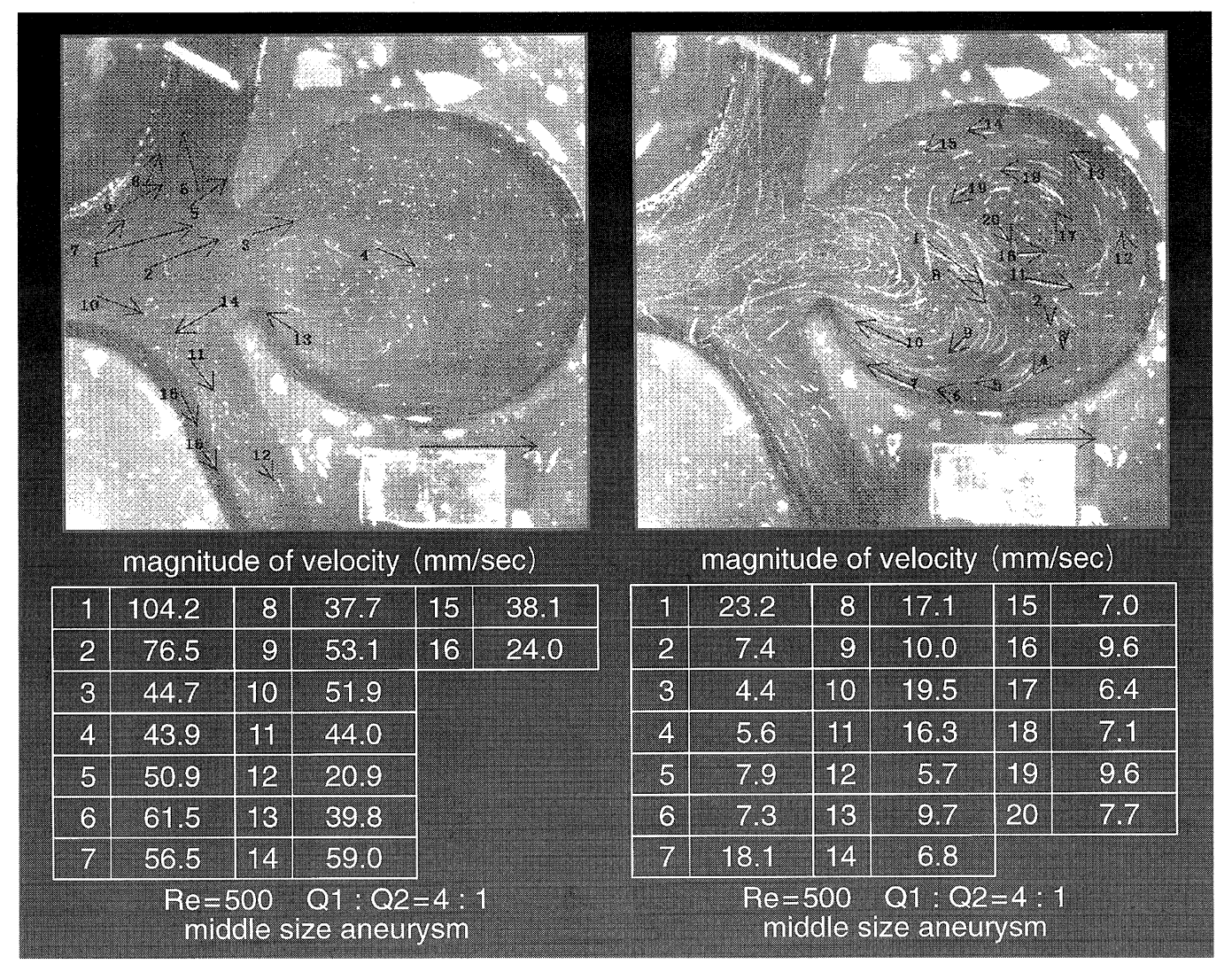

Fig. 4 Flow pattern of the standard aneurysm at a flow ratio into the distal branches of $4: 1$ and at a Reynold's number of 500. The line is the paths of the particles and the numbers on the paths indicate the particle linear velocity on the table. Left photograph shows the velocity pattern in the parent tube, and right photograph shows the velocity pattern in the aneurysm. The main flow smoothly enters into the aneurysm through the larger flow side orifice and making circulation with secondary vortices. The magnitude of the velocity of the secondary vortices decreases seriously. The flow goes out through the opposite orifice.

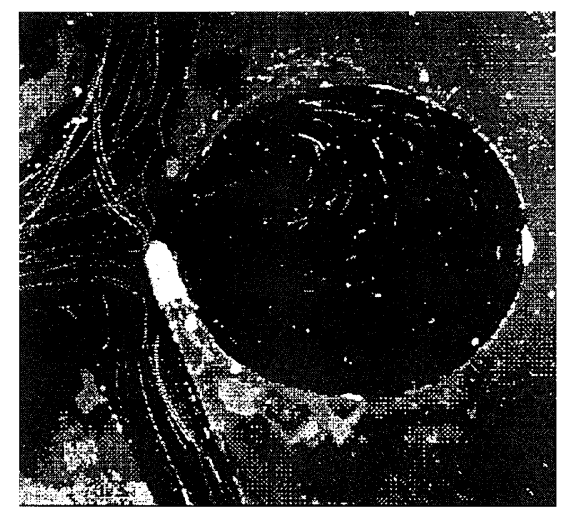

$\mathrm{Q} 1: \mathrm{Q} 2=4: 1$

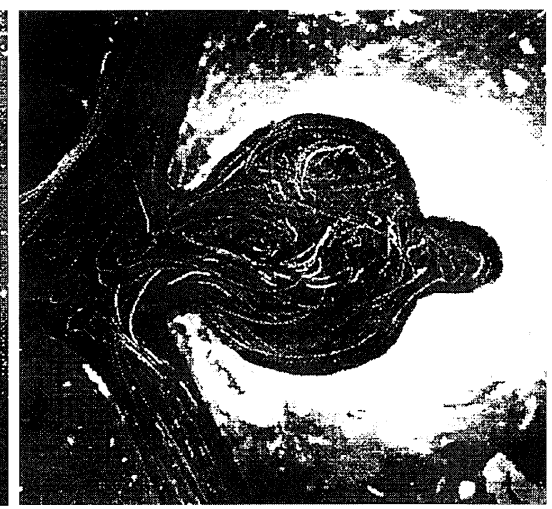

Q1 : Q2 = 4:1

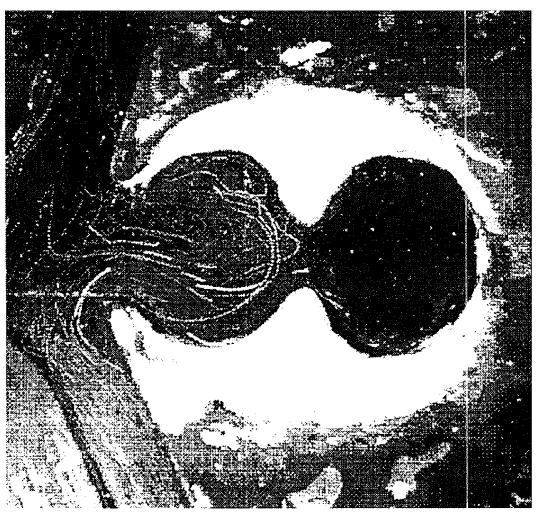

Q1 : Q2 = 4:1

Fig. 5 Flow patterns of the narrowing neck aneurysm, dumbbell shaped aneurysm and aneurysm with daughter aneurysm. The paths of particle are blocked by these changing geometries. Particularly the flow in the distal dome of the dumbbell shaped aneurysm is stagnant. 
Table 1

\begin{tabular}{l|ccc}
\hline & $\begin{array}{c}\text { Flow ratio } \\
\text { Q1/Q2 }\end{array}$ & MTT (sec) & $1 / M T T$ \\
\hline Standard & 1 & 201 & 0.00497 \\
aneurysm & 2 & 383 & 0.00261 \\
& 3 & 118 & 0.00844 \\
& 4 & 20 & 0.05145 \\
& 6 & 24 & 0.04092 \\
& 8 & 32 & 0.03099 \\
& 10 & 33 & 0.02999 \\
& Q2=0 & 54 & 0.01869 \\
\hline ange & 1 & 501 & 0.00199 \\
& 2 & 961 & 0.00104 \\
& 3 & 200 & 0.00499 \\
& 4 & 22 & 0.04733 \\
& 6 & 27 & 0.03648 \\
& 8 & 33 & 0.02991 \\
& 10 & 47 & 0.02133 \\
& Q2=0 & 43 & 0.02326 \\
\hline
\end{tabular}

であるため, 流れの流入部と流出部が同じ orificeを通っ てなされるので，この orifice を狭小化する neckの狭窄， dumbbell 型狭窄, bleb 形成は常に流入と流出の両方を防 げる。いわゆる破裂動脈瘤の形態学的特徵は，常に流れを 低下させた。

\section{動脈瘤内流量の測定}

動脈瘤内に染色液を満たしたのち，種々の流量比で定常 流を作成し, 動脈瘤内の染色液の濃度を CCD カメラでモ ニターした。すなわち, 動脈瘤全体の平均濃度を $\mathrm{Y}$ 軸に とり，時間をX軸にとり，濃度時間曲線を得た。この濃 度時間曲線を指数関数に近似することによって，MTTを 計算した. 動脈瘤内流れは, Table 1 に示すように流量比 が1：1および $2 ： 1$ のときにはきわめて遅く，3：1より 急激に上昇し， $4: 1$ で最大值を示し, 再び流量比の増大 とともに徐々に遅くなった。1/MTTを流量と考えるなら ば, 流量比が 4 ：1のときに動脈瘤の大きさにかかわらず, このモデルでは最大の動脈瘤内流量を示した. 流量比を 1：1から 10：1まで変化させたときの動脈瘤内流量を Fig. 6 に示した。

\section{考察}

\section{このモデル実験における制限}

われわれの用いたモデルが, rigidで平面的な三次元モ デルであること, 用いた流体が水であるため, 血液と違い その粘度は $1 / 4$ と低いこと, 作成した流れが拍動流でなく 定常流であること, これらの条件はきわめて非生理学的な

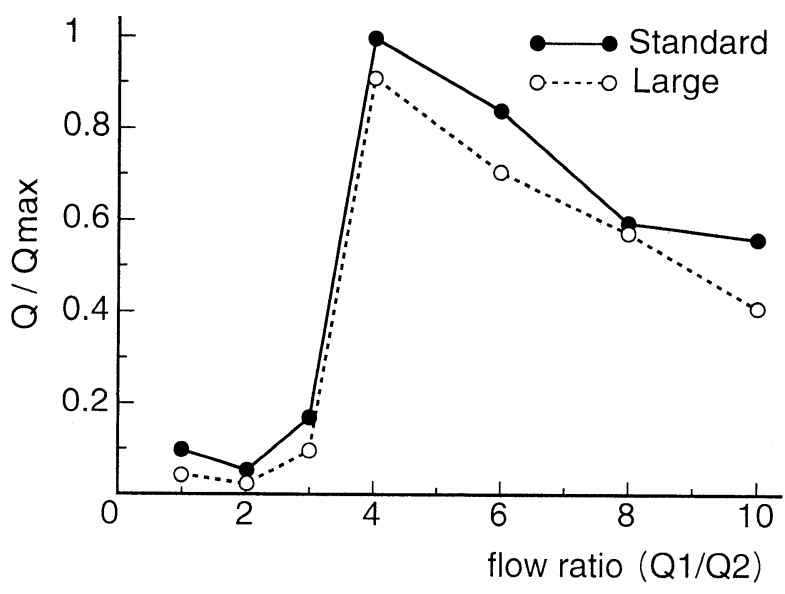

Fig. 6 The relation between the flow ratio and intraaneurysmal flow volume. Maximum intraaneurysmal flow is obtained at the flow ratio of $4: 1$ in both standard and large aneurysm. Below the flow ratio of $3: 1$ intraaneurysmal flow is very small.
状況を作り出していると考えられる. しかし中大脳動脈の 分岐部周囲の拍動流による血管径の変化は $4 \%$ と低く，ほ ほ rigid tubeとみなしてさしつかえないこと4)12), また血 液と水の粘度の差は, 使用したモデル内の流速を低下させ Reynolds 数を実際の生理学的条件と一致させることによ って，無視することが可能となること融11)12)，また拍動 流による変化は観察できないが, 定常流の速度条件を変化 させることによって収縮期, 拡張期の流れのパターンをお およそ推測できるので5) 13) 14)，このモデルを用いて得ら れた流れの特徴は, 実際の脳動脈瘤にも期待できると考え られる。

動脈瘤内の流れの基本パターンは, 動脈瘤が盲端の袋で あるため動脈瘤内への流入, 渦, そして動脈瘤外への流出 の 3 成分からなっている。この基本的な流れのパターンは Reynolds 数, 動脈瘤の大きさによって変化を受けないが, 末梢の流量比によって大きな変化を受けることがわかっ た. Reynolds 数が 300 前後の場合, 大きな動脈瘤では流 入速度が低下するため, 動脈瘤内の渦が十分に発達せず, 拡散流れになる場合があった。末梢の流量比が $1 ： 1$, 2：1というふうにその流速が導管内で対象的な双曲線分 布をとる場合, 動脈溜内への流入はきわ女て少ない.その ような場合には，動脈嵧内はよどみ流れとなっている。こ の傾向は末梢流量比が $3 ： 1 ４ ： 1$ となるに従って消失 し，動脈瘤内に大きな流れが生じる。しかしながら末梢流 量比が $3 ： 10$ 場合には動脈瘤 neckのところで流れの衝 突が生じており，一部の流れしか動脈瘤内に流れ込めず, またその流速もきわめて遅い. 
すなわち動脈瘤内の流入部と流出部ではその動圧に差が あり，その差が動脈瘤内の渦の大きさ，流れの速さを規定 していると考えられる。そのため動圧に差の生じない対象 的な速度分布を持った流れ（末梢流量比 $1 ： 1$ から $2 ： 1$ ) や差を少なくする流れ，すなわち Reynolds 数の低い流れ， そして動脈瘤内の流れの抵抗を大きくする場合, すなわち 動脈瘤内の volume が大きい場合, これらの場合では動脈 瘤内の流れはきわめて遅くなると考えられる。また動脈瘤 内に最大の流れを引き起こした場合でも（末梢流量比 4 ：

1)，その流速は近位部導管に比較して $1 / 4$ 近く遅い.

すなわちこれまでの報告と同じように，動脈瘤内の流れ はきわめて遅く，流れによって生じる shear stressもきわ めて小さい。われわれのモデルでは，よどみ流れを生じる 動脈瘤を観察することは簡単であるが, 実際このような状 態が生理学的に起こっているかどうか不明である。しかし われわれの実験に示したように，同じ流れの条件でneck を狭窄した場合, dumbbell型の狭窄を domeに作成した 場合, dome末梢にblebを作成した場合, それらの末梢領 域で流れはきわめて停滞する。この形態上の変化は, ヒト 動脈瘤では破裂脳動脈瘤の破裂部位と一致する。また大き な $2.5 \mathrm{~cm}$ を超える脳動脈瘤では血栓化の頻度がきわめて 高いことも, 遅い流れの結果血栓が生じた結果と考えられ, われわれの実験と一致する。すなわち流れの停滞と脳動脈 瘤の破裂には因果関係があるのではないかと推測される.

また対象的な流れを生じる対象的な分岐形態では，たと え動脈瘤があっても十分な流れが動脈瘤内に発生しないこ とがわかる.MRA，血管撮影などで，対象的な分岐形態 を示す対象的な分岐部には, 脳動脈瘤が発生しないという ことが推測される.

脳動脈瘤内に流れを引き起こす駆動力は，親動脈内の動 圧の差と考えられる。すなわち非対称流れでは，親動脈内 の流速 profile が対称的な双曲分布とはならず，流量の多 い末梢側へ最大流速べクトルがシフトするため, 分岐部で 流量の多い側と低い側で動圧の差が生じ，この差が動脈瘤 内の流れを生じる力となる。そのためどんな動脈瘤でも， 親動脈に比較して流れが遅くなることがわかる.

\section{結語}

今回の実験が示した事実は, 動脈瘤内の流れは動圧の差 で生じ，十分な動圧の差のない対称的分岐部では動脈瘤内 の流れが生じないこと, そして動脈瘤内の流れの停滞と動 脈瘤の破裂部位の形態的特徵が一致することである。今 後, 流れの停滞がどのように動脈瘤内の壁に生化学的変化 を生じ, 壁の脆弱化を招き破裂に至らしめるのか研究する 必要がある。

\section{文献}

1) Gobin YP, Counord JL, Flaud P, et al: In vitro study of dynamics in the parent vessel and effects of coil embolization. 36: 530-536, 1994

2) Gonzalez CF, Cho YI, Ortega HV, et al: Intracranial aneurysms: Flow analysis of their origin and progression. AJNR 13: 181-188, 1992

3) Hashimoto N. Hazama F: Experimentally induced cerebral aneurysms as model for non-surgical treatmen:. J Clin Neurosci 1: 266-273, 1994

4) King JT, Berlin JA, Flamm ES: Morbidity and mortality from elective surgery for asymptomatic, unruptured, intracranial aneurysms: A meta-analysis. J Neurosurg 81: 837-842, 1994

5) Liepsch DW, Steiger HJ, Poll A, et al: Hemodynamic stress in lateral saccular aneurysms. Biorheology 24: 689-710, 1987

6) Low M, Perktold K, Rauning R: Hemodynamics in rigid and distensible saccular aneurysms: a numerical study of pulsatile flow characteristics. Biorheology 30: 287-298, 1993

7) Nakagawa $T$, Hashi K: The incidence and treatment of asymmptomatic, unruptured cerebral aneurysms. J Neurosurg 80: 217-223, 1994

8) Perktold K, Gruber K, Kenner T, et al: Calculation of pulsatile flow and particle paths in an aneurysm-moclel. Basic Res Cardiol 79: 253-261, 1984

9) Perktold K, Kenner T, Hilbert D, et al: Numerical blood flow analysis: arterial bifurcation with a saccular aneurysm. Basic Res Cardiol 83: 24-31, 1988

10) Roach MR, Scott S, Ferguson GG: The hemodynamic importance of the geometry of bifurcations in the circle of Willis (glass model studies). Stroke 3: 255-267. 1972

11) Stehbens WE: Flow in glass models of arterial bifurcation and berry aneurysms at low Reynolds numbers. Quarterly J Exp Physiol 60: 181-192, 1975

12) Steiger HJ, Poll A, Liepsch DW, et al: Basic flow structure in saccular aneurysms: a flow visualization study. Heart Vessels 3: 55-65, 1987

13) Steiger HJ, Poll A, Liepsch DW, et al: Hemodynamic stress in terminal saccular aneurysms: laser-Doppler stucy. Heart Vessels 4: 162-169, 1988

14) Steiger HJ: Pathophysiology of development and rupture of cerebral aneurysms. Acta Neurochir Suppl 48: 1990

15) Strother CM, Graves VB, Rappe A: Aneurysm hemodynamics: an experimental study. AJNR 13: 1089-1095, 1992

16) Simkins TE, Stehbens WE: Vibrations recorded from the adventitial surface of experimental aneurysms and arteriovenous fistulas. Vasc Surg 8: 153-165, 1974

17) Suzuki J, Ohara H: Clinicopathological study of cerebral aneurysms origin, rupture, repair and growth. J Neurosurg 48: 505-514, 1978

18) Ujiie H, Liepsch DW, Goetz M, et al: Hemodynamic study of the anterior communicating artery. Stroke 27: 20862094, 1996

19) Wiebers DO, Torner JC, Meissner I: Impact of unruptured intracranial aneurysms on public health in the United State. Stroke 23: 1416-1419, 1992 